This is an Author's Accepted Manuscript of an article published in Contemporary Security Policy, Volume 26, Number 1, 2005, pp. (copyright Taylor \& Francis), available online at: http://www.tandfonline.com/doi/pdf/10.1080/13523260500116091\#.Uv4.jr6OcYkA

\title{
Regulating Private Military Companies: What Role for the EU?
}

\author{
ELKE KRAHMANN
}

\section{Introduction}

Following allegations that private security guards were involved in the torture of Iraqi prisoners and in the wake an attempted coup by private mercenaries in Equatorial Guinea the proliferation of so-called 'private military companies' (PMCs) is again receiving considerable attention. ${ }^{1}$ Of particular concern in the public and academic debate is the continuing lack of effective national and international controls of the industry. Much of this debate criticizes that international regulation has so far focused almost exclusively on mercenaries and has been bogged down by problems related to defining PMCs. Moreover, it is suggested that national controls on PMCs are lacking in most countries with the exception of the United States and South Africa.

This article seeks to show that this debate is systematically underestimating the level of national and international regulation of the sector and thus the possibility of strengthening existing controls. It suggests that in particular in Europe since the mid-1990s there has been a growth of national and international policies which directly or indirectly shape the provision and export of private military services. Moreover, this article argues that due to the specific dynamics of European integration these controls are not only increasing, but also converging within the European Union (EU).

To support these arguments, this article is divided into five sections. The first section presents an overview over the state of the debate on the regulation of PMCs. The second section examines the limits of this debate and argues that these limitations might be overcome with a different approach to private military operations focused on services rather than companies and the ways in which they might be regulated. The third and the fourth sections present the current level of national and international legislation in Europe which affect the provision and export of private military services in Europe and abroad. Finally, this article discusses the progress towards and prospects of an EU regime for the control of private military services. 
Private Military Companies and their Regulation: The State of the Debate Albeit recent events in Iraq have brought PMCs to the fore of media attention, the proliferation of private military contractors has been investigated in the academic literature since the late 1990s. ${ }^{2}$ The cause for this interest has been a perceived quantitative and qualitative shift in the use of private military forces. Not only has the scope of private armed forces grown significantly since the end of the Cold War, they have also taken on a new character through the emergence of private military firms with a corporate structure which distinguishes them clearly from the individual mercenaries of the 1960s.

In particular two, now disbanded, companies have shaped the image of the contemporary private military industry: the Bahama-registered, but Londonand Washington-based, company Sandline International and the South African private military firm Executive Outcomes. Both companies became notorious through their intervention in the civil wars in Sierra Leone and Angola. ${ }^{3}$ However, the intervention in Iraq has illustrated that private military companies are increasingly also employed by major Western powers as well as by a growing range of international organizations, private corporations and non-governmental organizations (NGOs) which operate in confiict regions. $^{4}$

Focused on these examples, the study of private military forces has primarily been concerned with the use of PMCs in failed states and regional confiicts. ${ }^{5}$ In particular, the literature points out two problems: On the one hand, many failed states lack sufficiently stable and capable national armed forces to provide for their own security or that of international actors seeking to alleviate the humanitarian problems caused by regional conflicts, on the other hand the same lack makes these actors particularly vulnerable to potential exploitation and power abuse by private military companies which are hired to improve security.

As a result of this conundrum, many authors highlight the potential of PMCs for peacemaking or peacekeeping in states and regions which have been wrecked by years of internal confiict. ${ }^{6}$ They argue that PMCs should not be conflated with traditional mercenaries. As registered companies which operate in a competitive market, PMCs are more likely to adhere to international norms and will refrain from excessive use of force or the exploitation of its customers. Thus, Doug Brooks contends: 'Companies fear retribution by their home governments for illegal or unethical operations, and recognize that a bad corporate reputation could result in the loss of future contracts to their competitors'. ${ }^{7}$ Moreover, Brooks and others argue that because private military companies do not require huge organizational structures, but draw mainly on lists of retired army personnel from the United States, the UK, 
and Eastern Europe, PMCs can 'offer military services more efficiently, more rapidly, and much more cheaply than state militaries or non-military companies could do themselves'.

At the same time, the literature recognizes the dangers posed by the use of PMCs in conflict regions. They contend that private military companies lack transparency, accountability and legitimacy. ${ }^{9}$ The use of PMCs in civil wars also exacerbates the spread of small arms and the militarization of conflictridden societies. ${ }^{10}$ Moreover, these authors note that PMCs are engaging in conflicts for purely commercial reasons. Close links between PMCs and extractive firms in the oil, diamond and mining industries are not unusual and can lead to the exploitation of unstable, but resource-rich countries. ${ }^{11}$ Finally, they argue that the positive effects of private military interventions are rarely long-lasting. When foreign or native governments end their contracts, the initial lack of a viable national security structure often reasserts itself and civil war re-erupts. ${ }^{12}$

Therefore, most authors appear to concur that if private military companies are here to stay, they should be controlled through international regulation. ${ }^{13}$ Yet, current attempts and future possibilities to control private military forces are generally viewed with scepticism. In particular, the literature identifies three problems. ${ }^{14}$ The first concerns the definition of mercenaries and private military companies for the purpose of regulating them. ${ }^{15}$ The second problem is a perceived lack of interest among governments in the control of private military forces. ${ }^{16}$ The third is the transnational character of most PMCs which allows them to evade anything but global controls. ${ }^{17}$ These problems, it is argued, explain why any effort to regulate mercenaries and PMCs short of an international regime would fail. However, they are also used to illustrate why national and international regulation has so far been limited.

The United Nations International Convention Against the Recruitment, Use, Financing and Training of Mercenaries 1989 is typically presented as the key example of the problems which characterize attempts to control the private military industry. ${ }^{18}$ The UN International Convention on Mercenaries has been marred by difficulties associated with a common definition of mercenaries and the reluctance among members of the international community to sign up to the convention. The definition of mercenaries embraced by the convention is based on the Additional Protocol I of the Geneva Convention which stipulates that a mercenary is any person who is specially recruited to fight in armed conflict, does take direct part in hostilities, is motivated essentially by the desire for private gain, is neither a national nor a party to the conflict, is not a member of the armed forces and has not been sent by another state as a member of its armed forces. ${ }^{19}$ However, since the definition presumes that is it possible to analyze and prove the motivation of mercenaries 
and since it requires that all criteria have to be met simultaneously, it is nearly impossible to convict any combatant as mercenary.

Another attempt at regulating mercenaries which is widely criticized is the Organization of African Unity (OAU) Convention for the Elimination of Mercenaries in Africa, which was opened for signature in 1977 and entered into force in $1985 .{ }^{20}$ The OAU Convention, like the UN International Convention on Mercenaries, uses the definition of mercenaries of the Additional Protocol I and thus suffers from similar problems.

Finally, the literature points out that few countries have national regulations specifically designed to control private military companies - the only exceptions currently being the United States and South Africa. ${ }^{21}$

\section{From Africa to Europe: Moving Beyond the Current Debate}

The preceding analysis points to three problems with the current debate over the regulations of PMCs. The first is the predominant focus on 'mercenary', i.e. combat, companies and their operation in failed states and regional conflicts. The second problem is the definition of PMCs and mercenaries in the literature and contemporary legislation, and the third is the narrow conception of existing and possible regulation of PMCs.

This section argues that a comprehensive analysis of the regulation of private military service, and the potential role of the EU in it, needs to move beyond the current state of the debate. Specifically, it suggests three interlinked modifications: a broadening of the analysis of the privatization of military services from Africa to Europe and North America, a definition of private military contracts in terms of the services provided and not of the companies which provide them, and, finally, a broadened understanding of the means by which PMCs are and can be controlled. The following outlines the arguments for each of these modifications in turn.

As the preceding section has argued, mercenary companies such as Sandline International and Executive Outcomes and their respective involvement in the civil wars in Sierra Leone and Angola represent only a very small selection of cases in the universe of PMCs and their operations. The majority of PMCs are providing more often military logistics and maintenance than combat soldiers and work for industrialized countries rather than developing nations in Africa. In fact, most private military and military support services are provided in military bases in Europe and North America. ${ }^{22}$ These services range from the management of military facilities and the training of fighter pilots to the maintenance of vehicles, ships and planes. However, PMCs also support international interventions such as in the former Yugoslavia, Afghanistan and Iraq. 
The extensive use of private military contractors in Iraq illustrates that the biggest market for PMCs is not in the Third World, but among the major military powers in Europe and North America. The growing interventionism of these powers and the resultant overstretch of their armed forces, which had been cut back after the end of the Cold War, fosters this development. In Iraq, one in ten US personnel on the ground is a private contractor, whereas in the Gulf war the ratio had been one in $50 .^{23}$

Many of the larger companies operating in Iraq are based in Europe. ${ }^{24}$ This includes Aegis Defence Services, the new company of Lieutenant-Colonel Tim Spicer who formerly headed Sandline International, which was awarded a $\$ 293 \mathrm{~m}$ contract by the US to coordinate security companies working in Iraq; ${ }^{25}$ ArmorGroup, now chaired by former UK Foreign Secretary Sir Malcolm Rifkind, which currently has 'more than 1400 employees providing security, specialist training and mine action/UXO services in support of many of the key reconstruction programs in Iraq $;{ }^{\prime 26}$ Erinys, which is contracted to provide protection for Iraq's oil pipeline and offers 'site security and mobile security teams, convoy protection, diplomatic protection, key point and personal protective services' for international companies and organizations $;{ }^{27}$ and Control Risks Group, which is, among others, employed by the UK Foreign and Commonwealth Office for personal security services. ${ }^{28}$ Most of the other major players are registered in the United States such as Kellogg Brown and Root, a subsidiary of Halliburton, which provides logistics for the US armed forces; DynCorp which holds a $\$ 50$ million contract for the support of public security; ${ }^{29}$ and the Vinnell Corporation, a subsidiary of Northrop Grumman, which has been awarded a $\$ 48$ million contract for the training of the new Iraqi army. ${ }^{30}$

Closely linked to the broadening of the analysis of the privatization of military services from developing countries in Africa to industrialized nations in Europe and North America is the need for a different conceptual approach to private military operations. Such a definition should recognize the full range of private military services and the variety of companies which offer them. The latter has been exacerbated by changes in the private military and security sector which had led a growing number of private security, private policing and private armaments companies to offer military-related services. ${ }^{31}$

The conventional distinction between three types of private military companies, i.e. mercenary firms, private military firms and private security firms, ${ }^{32}$ therefore misrepresents the composition and size of the industry. Although most authors recognize that these categories are at best ideal-types and that many companies provide functions across these areas, private security companies, policing firms and armaments corporations are typically perceived as distinct from PMCs and mercenaries with direct consequences for both the analysis of the industry and efforts to regulate it. 
This article suggests that a definition of private military force in terms of the services provided rather than the nature of the companies which offer them is more suited to the study and regulation of the sector. ${ }^{33}$ Accordingly 'private' military services could be defined as services directly related to the provision of national security and to international interventions if they are offered by registered companies. A list of such services includes combat; personal and site security where this relates to the personnel and bases of governments or international organizations and NGOs operating in conflict regions; military training and advice; security consulting; technical support for the operation and maintenance of military equipment; procurement, trafficking and brokering of military equipment; explosive ordnance disposal; logistical support for military operations and bases; intelligence collection and analysis including the interrogation of military prisoners. ${ }^{34}$ Crucially, a service-based definition recognizes that various types of companies can provide these services ranging from arms corporations to risk consultancies. Moreover, a regulation which controls services rather than companies may apply to one firm in respect to a particular contract, but necessarily to all its business.

Although a service-based definition might initially seem confusing and difficult to implement in terms of legislation, it is common practice in defence export regulation. In fact, most attempts to control military exports are regulated through lists of controlled goods rather than through a regulation of the companies which sell them. Armaments exports and the transfer of dualuse goods, i.e. goods with civil and military applications, are thus legislated and any company regardless of whether it defines itself as a 'defence corporation' or an 'electronics firm' is required to apply for a licence for any contract that includes the export of sensitive technology. Moreover, as will be argued in more detail below, the European Union has adopted a similar approach to control what it calls 'technical assistance' related to listed military equipment and activities.

A different conceptualization and definition of private military force has important implications for the analysis and prospects of the regulation of private military services. In particular, this definition reveals that private military services and the companies which offer them are currently regulated by a broader range of legislative measures than has been recognized by the media and the academic literature. Moreover, it suggests new and different forms of regulatory controls for the future. In Europe, these legislative measures range at the national level from the registration and regulation of private policing and security firms to the control of armaments exports and arms brokering. At the level of the EU, they include the European Code of Conduct on Armaments Exports and a range of Common Foreign and Security Policies concerning the transfer of sensitive technology and services to countries such as the 
former Yugoslavia. The following two sections examine the controls at each level before discussing the dynamics which have led to the strengthening and convergence of national and international regulation since the late 1990s.

\section{National Regulations within the EU}

National regulation of private military services among the EU member states can be divided into three categories: the control of private security and policing services, the licensing of armaments exports, and the regulation of mercenaries and private military companies.

\section{Private Policing}

At the national level, the regulation of private security and policing is one of the key areas which influence the provision of private military services in the EU. Specifically, private military services fall under these controls where they involve the protection of property or people, where security personnel carries arms or where it regards the gathering of intelligence. Not commonly covered by these regulations are services related to military training, logistics or consulting, although this depends on the definition of private security services embraced by different countries and the level of regulation. An overview of national legislation on private security services among the $25 \mathrm{EU}$ member states has been produced by the European Confederation of Security Services (CoESS) and shows significant differences in both areas. ${ }^{35}$ Some European countries, such as Denmark, Finland, France, Portugal and Spain, have strict and comprehensive controls. Others, such as Italy, have only narrowly defined regulations. ${ }^{36}$ What seems notable, however, is that from the $1990 \mathrm{~s}$ nearly all European governments have stepped up their control of private security and policing services.

The prime mechanisms regulating private security and military services in the EU member states are the national registration and licensing of security companies and their personnel. ${ }^{37}$ The conditions for a licence, which on average needs to be renewed every five years, vary among the member states. However, all member states require a clear criminal record among management and personnel. Additional conditions include sufficient liability insurance, identification cards with name and photo, and approved uniforms which are not easily confused with those of the police or armed forces. ${ }^{38}$

About 60 per cent of the EU member states mandate specific training of private security personnel and the passing of an examination. ${ }^{39}$ Training can range from basic instruction of between 32 (France) and 300 hours (Poland) to complementary and follow-up training, including for the protection of persons, the transport of valuables and the use of fire arms. With the exception of Denmark, France, the Netherlands and the UK, most member states allow 
for the carrying of fire arms by security personnel with a special permit. Nevertheless, many states limit and request registration of the type and number of weapons concerned, and most mandate that after-hour storage has to be in special facilities. ${ }^{40}$

It follows that any private security company registered in one of the EU member states, even if hired for personal or site protection in countries such as Iraq, will have been required to go through a substantial vetting process. Although these conditions are only enforced within the territory of the regulating state, they are likely to improve the level of training and accountability among the major international companies based in Europe. Moreover, as will be discussed further below, the requirements of the internal market within the EU are increasing the pressure to regulate the provision of private security and military services across national boundaries. Already some export controls affecting the operation of private security companies abroad can be found in national legislation on armaments transfers.

\section{Armaments Exports}

While European regulations of private security and policing services so far fail to control the international transfer of military services, such export controls can be part of national legislation on defence exports. Specifically, national defence export legislation can include the prohibition or licensing of services such as trafficking and brokering in arms, technical assistance related to controlled military goods, and, in the case of Sweden, military training. Some of these controls have been the result of recent decisions within the EU; others have already been part of national legislation for some time.

In particular, the EU Council Joint Action 2000/410 of 22 June 2002 has encouraged controls of technical assistance related to certain military end-uses or destinations among the member states. ${ }^{41}$ The proposed regulations concern technical assistance related to items "which are or may be intended for use in connection with weapons of mass destruction or missiles for delivery of such weapons' ${ }^{42}$ Crucially, 'assistance' as defined by the EU Joint Action covers nearly the entire spectrum of private military services, including 'technical support related to repairs, development, manufacture, assembly, testing, maintenance, or any other technical service, and may take forms such as instruction, training, transmission of working knowledge or skills or consulting services'. Moreover, the Joint Action encourages member states to 'consider the application of such controls also in cases where the technical assistance relates to military end-uses other than those referred to in Article $2 \ldots$ and is provided in countries of destination subject to an arms embargo'. In sum, the Council suggests national legislation regarding the export of private military services related to chemical, biological or nuclear weapons as well as to any country subject to international arms sanctions. 
The second EU guideline for national export controls is the Council Common Position 2003/468/CFSP which sets out a range of provisions for the regulation of armaments brokering. Crucially, the Common Position requires member states to implement these guidelines though national legislation. ${ }^{43}$ The stated objective of the Common Position 2003/468/CFSP is 'to control arms brokering in order to avoid circumvention of UN, EU or OSCE embargoes on arms exports, as well as of the Criteria set out in the EU Code of Arms Exports'. The Common Position mandates that 'member states will take all necessary measures to control brokering activities taking place within their territory', but also 'encourages' member states 'to consider controlling brokering activities outside their territory carried out by brokers of their nationality resident or established in their territory'. ${ }^{44}$

Since there exists no comprehensive overview of national arms export controls or the implementation of these guidelines among the EU member states, the following will focus on countries which offer the relevant information in English as illustrative examples. They include Germany, the United Kingdom, Italy, and to some degree France, Belgium, the Netherlands, Luxembourg, Finland and Sweden.

The transfer of technical assistance related to WMDs and embargoed countries is controlled in Germany through the revised Export Regulation (Aussenwirtschaftsverordnung) of 2002. The regulation specifically requires the authorization of the transfer of technical assistance related to WMD or to embargoed countries if provided by residents and to non-resident Germans. ${ }^{45}$ Moreover, Germany also mandates licensing for technical assistance related to WMD if it is provided on European Community territory. ${ }^{46}$ In the United Kingdom technical assistance falls under the specifications of the new Export of Goods, Transfer of Technology and Provision of Technical Assistance (Control) Order 2003. However, the UK law only regulates technical assistance with regard to WMD and if provided outside the EU. ${ }^{47}$ In Italy, the European Common Position regarding technical assistance has been implemented through the Legislative Decree No.96 of 9 April 2003. ${ }^{48}$ Although the decree applies to both WMD and embargoed countries, it is more limited than the German and UK regulations in its definition of 'technical assistance'. Included in the Italian definition are only the 'incorporation into military items', 'the use of production-, test-, or analytical equipment' and the 'use of any unfinished products in a plant for the production of [restricted] military items'. ${ }^{49}$

Following the EU Common Position, the trafficking and brokering in arms are also controlled in Germany and the $\mathrm{UK}^{50}$ and similar national regulations have been implemented or are in the process of being implemented in France, Belgium, the Netherlands, Luxembourg, Finland and Sweden. ${ }^{51}$ The new German export regulations demand the authorization of trafficking and 
brokering in arms listed in the national control list or to countries subject to an embargo if they are conducted by German residents. In the UK, the trafficking and brokering of controlled goods to embargoed and non-embargoed destinations are regulated through the Trade in Goods (Control) Order 2003 and the Trade in Controlled Goods (Embargoed Destinations) Order $2004 .^{52}$ The former regulates the trafficking and brokering in restricted goods by UK persons or companies and persons in the UK. ${ }^{53}$ The latter requires that no UK person or company and person in the UK shall directly or indirectly supply or deliver any controlled goods to any person or place in an embargoed destination. ${ }^{54}$ France has also proposed legislation requiring a licence for brokering activity conducted within the country, but not French citizens living abroad, ${ }^{55}$ whereas Finland asks for licences to broker defence material within Finland as well as of Finnish citizens, Finnish corporations, and foreign citizens considered permanent residents in Finland who broker outside Finnish territory. ${ }^{56}$ Sweden has perhaps the most extensive controls as the Swedish Military Equipment Act requires licences for all types of defence industry cooperation with foreign partners, including not only the transfer of ownership and manufacturing rights, but also brokerage for Swedish authorities, companies and persons who are resident or permanently domiciled in Sweden. ${ }^{57}$ Moreover, the Swedish law is unique in Europe in demanding licences for the provision of military-oriented training. ${ }^{58}$

\section{Mercenaries and Private Military Services}

Although many European countries have national legislation prohibiting the recruitment of mercenaries ${ }^{59}$ no member state of the EU has so far implemented specific regulations for the provision and export of private military services. A British Green Paper on the options for such regulations entitled 'Private Military Companies: Options for Regulation' ${ }^{60}$ which was drawn up in 2002, however, is currently being re-examined in the light of recent experiences in Iraq $^{61}$ and is thus worth investigating.

The UK Green Paper begins by noting the definitional problems which have hampered the UN and OAU efforts to control mercenaries and PMCs. As a consequence, it examines the regulation of private military services and lists a variety of control options as well as the advantages and disadvantages of each. ${ }^{62}$ Specifically, the Green Paper evaluates three proposals: a national and international ban on mercenary activity, national licensing of PMCs and exports, and the self-regulation of the industry. The first option would be the most effective, but is dismissed by both the Green Paper and a subsequent report from the House of Commons Foreign Affairs Committee on the grounds that it would be too difficult to enforce because of the problem of defining mercenary activities, would 'deprive weak but legitimate 
113

governments of needed support', and would deprive British defence exporters of legitimate business. ${ }^{63}$

The second option appears to be favoured by both documents, although there are different possible variations on the degree and form of national licensing. The Green Paper specifically discusses the licensing of contracts for military and security services abroad. It states that activities for which licences may be required might include:

recruitment and management of personnel, procurement and maintenance of equipment, advice, training, intelligence and logistical support as well as combat operations.... For services for which licences were required, companies or individuals would apply for licences in the same way as they do for licences to export arms (though not necessarily to the same Government Department). Criteria for the export of services would be established on the same lines as those for exports of arms. ${ }^{64}$

In addition, the Green Paper raises the possibility of a registration of PMCs, the notification of the government of contracts for which companies are bidding, and a general licence for private military services to a specified list of countries. ${ }^{65}$ Conversely, the Green Paper seems most sceptical of the last option, arguing that it 'would provide little protection for the public interest ${ }^{66}{ }^{66}$ However, the Green Paper admits that a general licence could be used in conjunction with other regulatory measures. The Foreign Affairs Committee report broadly follows this line by recommending that 'each contract for a military/security operation overseas should be subject to a separate licence, with the exception of companies engaged in the provision of noncontinuous services for whom the Government considers a general licence would suffice' ${ }^{67}$ However, the Committee also supports that 'private military and security companies be required to obtain a general licence before undertaking any permitted military/security activities overseas ${ }^{68}$

The third option of encouraging the self-regulation of the private security industry is considered insufficient in both documents because it would prevent the government from restraining private security companies which were acting contrary to British national interests abroad. ${ }^{69}$

\section{International Regulation through the European Union}

International regulation of private military services through the EU can also be divided into three categories: the harmonization of national regulations on private policing, the Common Foreign and Security Policy (CFSP) and the EU Code of Conduct on Arms Exports. ${ }^{70}$ 


\section{Private Policing}

As the preceding section has illustrated, national regulations of private policing and security vary widely within the EU and thus also their influence on the provision of private military services. Nevertheless, the area of private policing has potentially the broadest implications for the international regulation of the private military sector because it technically falls under the competences of the EU. The European Court of Justice has established this competence in several rulings according to which private security counts as an 'economic sector' and as such falls under the regulation of the internal market. ${ }^{71}$ However, the movement towards common European regulations on private policing has so far been rather slow. A Spanish initiative concerning the establishment of a network of contact points of national authorities responsible for private security was rejected by the European Parliament for formal reasons. ${ }^{72}$ However, the committee of the European Parliament in charge of the issue was in favour of harmonizing member states' regulations of the private security sector and the Council adopted on 13 June 2002 a recommendation regarding the cooperation between the competent national authorities of member states responsible for the private security sector. ${ }^{73}$ Further pressure for common European regulations is exerted by the Confederation of European Security Services (CoESS) and the trade union federation Uni-Europa which signed on 18 July 2003 a Code of Conduct for the private security sector. The sectoral social partners believe 'that the rules governing their sector need to be harmonized across the EU. This will be particular important when the ten new member states will join the EU next year'. ${ }^{74}$

\section{Common Foreign and Security Policy}

While the harmonization of private policing legislation within the EU is a prospect for the future, the Common Foreign and Security Policy (CFSP) of the EU has already been used to control the export of some types of private military services, such as the transfer of services related to WMD and embargoed destinations, the trafficking and brokering of arms, the spread of small arms and light weapons, and the maintenance and use of military equipment. As has been illustrated above, the first two have been endorsed through Joint Actions and Common Positions requesting national legislations.

More directly, however, the EU has used ad hoc Regulations at the EU level to control the export of private military services to certain destinations in response to civil wars and regional conflicts. Specifically, the transfer of technical services related to military equipment and activities has progressively been the target of EU restrictions since the mid-1990s. ${ }^{75}$ Thus, in January 2005, no less than seven countries, Congo, Ivory Coast, Liberia, Myanmar/Burma, Somalia, Sudan and Zimbabwe, were subject to an 
EU-wide embargo of technical services related to military activities. ${ }^{76}$ Previously, similar restrictions on the transfer of military technology and services have been applied to Afghanistan, ${ }^{77}$ Ethiopia and Eritrea, ${ }^{78}$ the former Yugoslavia, ${ }^{79}$ Libya $^{80}$ and Nigeria. ${ }^{81}$

Crucially, the EU definition of 'technical services' in most of these Regulations is considerably broader than those embraced in many of the national export legislations examined above. In the case of Liberia, for instance, it includes 'technical training or assistance related to the provision, manufacture, maintenance or use of arms and related material of all types including weapons and ammunition, military vehicles and equipment, paramilitary equipment and spare parts for the aforementioned'. ${ }^{82}$

Further Joint Actions have been adopted regarding the transfer of small arms and light weapons, which can be facilitated by the operations of PMCs in developing countries. ${ }^{83}$ In 1998, the Council thus adopted Joint Action 1999/34/CFSP on the EU contribution to combating the destabilizing accumulation and spread of small arms and light weapons. ${ }^{84}$ Amongst others, the Joint Action envisaged that the EU shall enhance efforts to build a consensus in international organizations such as the United Nations and the OSCE for restrictive arms export criteria as provided in the EU Code of Conduct. Moreover, the Joint Action proposes that member states 'shall seek to increase the effectiveness of their national actions in the field of small arms ${ }^{85}$

In 2002, it was replaced by Joint Action 2002/589/CFSP which also included the export of ammunition for small arms and light weapons and expanded the list of measures sought to counter the spread of small arms. ${ }^{86}$ In direct application of the Joint Actions, the Council passed two Decisions which offered the government of Cambodia assistance in the development of appropriate legislation for the possession, use and sale of small arms and ammunitions and for general disarmament measures.87 Other projects directed at the finding, collection and destruction of small arms were agreed on with regard to Georgia/South Ossetia ${ }^{88}$ and Mozambique (Operation Rachel). ${ }^{89}$

\section{Code of Conduct on Arms Exports}

Another element which has emerged out of the Common Foreign and Security Policy is the EU Code of Conduct on Armaments Exports. ${ }^{90}$ The Code of Conduct was drawn up in June 1998 in order to set high common standards for conventional arms transfers and to facilitate the exchange of information about arms exports among member states. Furthermore, the Code of Conduct called for the circulation among the member states of confidential annual reports on their arms exports and the implementation of the Code, as well as for the production of a consolidated report by the EU. The first such report was published in November 1999. ${ }^{91}$ It was four pages long and observed the initial efforts to establish institutional channels of 
communication on arms transfers among the member states. Since then the detail of each report has increased every year. ${ }^{92}$ The fifth report published in December 2003 was 42 pages long and included lists of arms export volumes by country destinations and exporting member states. ${ }^{93}$ Moreover, since all member states are required to produce annual national reports as the basis for the consolidated report, many member states have decided to also make their national data on armaments exports public.

The impact of the Code of Conduct has not only been the increase of transparency concerning armaments exports from the EU, but also the growing harmonization of national arms export legislation discussed in the preceding section. The harmonization of arms controls is particularly important because it makes it more difficult for PMCs to evade national controls by settling in those member states with the least restrictive regulations. Mercenary companies may still be able to move offshore. But companies which offer services concerning the operation, management and maintenance of military equipment frequently rely on the skilled labour forces available in European countries and are less flexible. Since harmonization has typically between implemented in the form of stricter controls among member states, the Code of Conduct has strengthened the regulation of private military services. As the preceding section has illustrated, most EU member states have thus increased the range of national controls which apply to the transfer of private military services, such as trafficking and brokering of arms or the maintenance and operation of military equipment in countries subject to international embargoes. Moreover, with the enlargement of the EU, the number of countries subscribing to the export control standards endorsed in the Code has increased from 12 to 25. Already before accession, most aspirant countries had aligned themselves to the Code of Conduct and a number of associated or allied countries have embarked upon measures to tighten their national export controls in line with the Code, including Turkey, Croatia, the EFTA countries and Canada. ${ }^{94}$ Finally, in December 2000 the EU and the United States agreed on a US ' EU Declaration on Responsibility in Arms Exports. ${ }^{95}$

The case of controls over the trafficking and brokering of arms illustrates the success of the Code of Conduct and, in its execution, the Council's Conventional Arms Exports Working Group (COARM) in strengthening national controls. The member states first identified the issue of brokering as a key problem in their annual report on the implementation of the Code in 2000. They wrote: 'The member states intend to continue and deepen their discussions on the procedures for monitoring arms brokers' activities in order to incorporate this special topic - the importance of which has been recognized into the process of convergence of the member states' control policies' ${ }^{96} \mathrm{By}$ 2001 , member states had agreed on a set of guidelines for controlling brokering as the basis for national legislation. ${ }^{97}$ The result, as mentioned above, has 
been the Council Common Position on the control of arms brokering passed in June 2003 which has made binding the national regulation of brokering among the member states. 98

\section{The Dynamics and Future of EU Controls of Private Military Services}

The preceding sections have illustrated that the range of regulative measures which control the domestic provision and international export of private military services in Europe is much more comprehensive than typically noted. Although some authors and organizations criticize the still limited scope and insufficient implementation of existing arms and military service regulations in Europe, ${ }^{99}$ the above has demonstrated that the member states of the EU are progressively recognizing the importance of regulating not only the export of military equipment, but also of related services. In addition, the particular dynamics of policy making within the EU, such as the pressures for the harmonization of national legislation, have contributed to the strengthening of controls. This section analyzes how the regulation of private military services has increased progressively since the mid-1990s. Moreover, based on these developments it discusses the prospects of a common European regime for military service exports.

The regulation of private military services in Europe appears to have progressed along two axes: functionally and geographically. On the functional axis, one can note attempts to control the 'soft' end of private security services, such as private investigation and policing, on the one hand, and the 'hard' end, such as mercenaries and PMCs, on the other. On the geographical axis, there appear to be simultaneous efforts to regulate private military services from the national and the international arena. The advantage of these concurrent developments seems to be the evolution of a system of multilevel governance of the private security sector in which overlapping regulations and regional institutions and regimes strengthen each other. Disadvantages include the complexity and inconsistency of the emerging controls which currently leave loopholes for PMCs and which put a heavy administrative burden on regulators.

Crucially, both axes converge within the EU, allowing it to play a central role in determining the future regulation of private military services. Along the functional axis, the EU is, on the one hand, under increasing pressure to harmonize or even integrate the regulation of private security services among the member states due to the rulings of the Court of Justice which suggest that private security services should operate under the conditions of the internal market. On the other hand, the EU is progressively laying out common standards for the export of military equipment and services under the Code of Conduct on Arms Exports and through Joint Actions and Common Positions 
under the CFSP. Along the geographical axis, the EU influences national regulations through common European standards and vice versa. Moreover, the EU takes an active role in the geographical expansion of its control standards within the international community both through enlargement and bilateral agreements with other states.

As a consequence of this conversion, the EU has been put into a position of considerable influence and authority over the expansion of private military service controls. Moreover, the EU has been taking an active role in furthering military service regulation. This role appears to be driven by two factors: integration and the outside representation of the EU. The growing scope and convergence of national legislation on private policing services, which has been characterized by requirements for registration, more extensive training and the vetting of private policing personnel, can thus be explained by the pressures for the harmonization of national controls in support of the internal market. While so far the EU has not taken a direct role in the establishment of common control standards, the European Court of Justice has already asserted the authority of the Union on this issue through its rulings. Combined with the pressure from companies, employers' associations such as the CoESS and European labour unions, it therefore appears to be merely a question of time before the EU will proceed to establish common standards for the regulation of private policing services ' at least within the territory of the Union. A precedent for a common regime was set in 1998 with the EU controls on dualuse goods, i.e. goods with civil and military applications, which could be used as a model for or to subsume the regulation of private military services. 100

At the same time, national arms control policies are increasingly affected by coordination through common foreign and security policies as member states aim to increase their international leverage by using the EU as their representative in international fora, such as the United Nations, the OSCE or the Wassenaar Agreement. While initially, the EU appears to have merely endorsed international arms controls agreements and embargoes through subsequent Joint Actions and Regulations, today its stated goal is to influence the level of international controls by promoting EU standards. New legislation on private military services, such as the transfer of small arms and light weapons, trafficking and brokering and the export of technical assistance, among the member states has been a direct consequence of these developments within the EU. Of course it needs to be noted that so far not all member states have implemented these policies and that the level of national controls can vary in significant details. However, pressures for common and higher control standards can only be expected to rise in the long term and with it the role of the EU in negotiating them.

The growing geographical scope of private military service regulations can also be linked to the EU. In particular, the preceding section has shown 
that European enlargement and with it the extension of the internal market have encouraged prospective member states and states which seek closer economic relations with the EU to harmonize their export controls with those of the current members. The geographical expansion of private military service controls is further facilitated by the above-mentioned policies of the EU regarding the common representation of the member states in international organizations and control regimes and common foreign and security policies directed at the internationalization of EU export control standards. Both enlargement and CFSP are thus likely to help spread stricter regulations for the transfer of private military services from the regional to the international level.

\section{Conclusion}

The aim of this article has been to broaden our understanding of the extent and potential of national and international regulation concerning the provision and export of private military services in Europe. To do so, it has proposed three modifications to the current debate over PMCs.

First, the preceding discussion has proposed to widen the scope for the analysis of private military forces in definitional and geographical terms. Thus, it has argued that the predominant focus on mercenaries and combat companies is misleading since it excludes from the analysis private military services which are provided by other actors, such as defence corporations and private security firms. More suitable appears to be a definition which is based on the types of services which should be controlled rather than the actors which offer these services. In addition, this article has argued that a comprehensive analysis of the proliferation and regulation of private military services should recognize that the primary growth market for private military and military support services is not among failed states in Africa, but among the industrialized nations of Europe and North America.

Second and because of this broader analysis, the preceding sections have been able to illustrate that the regulation of private military services extends beyond the national and international regimes on mercenaries and PMCs. Other relevant control measures include national legislation on private security and policing firms, the regulation of arms exports and the common foreign and security policies of the EU.

Third, because of the diverse array of control mechanisms which directly or indirectly infiuence the private military service sector in Europe and because of the variety of national and international organizations involved in the regulation of private military force, this article has contended that other factors than supply and demand or national interest play a growing role in shaping these controls. The institutional dynamics of the EU are particularly central. Thus, this article has sought to illustrate that the interaction 
between the harmonizing pressures of the internal market and the increasing role of the EU in representing its member states in international regimes and organizations have contributed to the tightening of private military service controls since the mid-1990s.

What are the consequences of this analysis for the debate over the regulation of private military services' Most contemporary efforts to control the growing private military sector have aimed towards new, preferably global, regimes on mercenaries and PMCs. However, in order to function, these regimes not only need the support of a sufficient number of signatories, they also require a strong normative commitment in the absence of global monitoring mechanisms or effective sanctions. As a consequence, progress on a global regime for private military services has been limited. The United Nations Convention on Mercenaries has few signatories and even more restricted application.

This article suggests that there might be a faster and more effective way to enhance the regulation of private military services. It shows that overlapping national and international regulations, while not perfect, can create a dynamic by which a centrally placed actor such as the European Union can exploit pressures for harmonization and integration in favour of more comprehensive control mechanisms. For European governments the appeal is that common and extensive international controls will be more cost efficient and easier to implement than national controls since they eliminate duplication, whereas the industry is likely to support such regulations because it will eliminate competitive disadvantages. Recognizing both, the EU appears to have accepted this role.

\section{ACKNOWLEDGEMENT}

This research was funded by the United States Institute of Peace (USIP), grant reference RW8996. The views expressed in this article are the author's and do not represent those of USIP.

\section{NOTES}

1. Antony Barnett and Patrick Smith, 'British Guard Firm "Abused Scared Iraqi Shepherd Boy", Guardian, 14 Nov. 2004; Jamie Wilson, David Pallister and Paul Lashmar, 'Thatcher and a Very African Coup', Guardian, 26 Aug. 2004.

2. Juan Carlos Zarate, 'The Emergence of a New Dog of War: Private International Security Companies, International Law and the New World Disorder', Stanford Journal of International Law, Vol.34, No.1 (1998), pp.75-162; Guy Arnold, Mercenaries. The Scourge of the Third World (Basingstoke: Macmillan, 1999).

3. Gerry Cleaver, 'Subcontracting Military Power: The Privatization of Security in Contemporary Sub-Saharan Africa', Crime, Law and Social Change, Vol.33, No.1-2 (2000), pp.13149, at pp.140-43; Herbert Howe, 'Global Order and Security Privatization', Strategic Forum, No.140 (May 1998), available from forum140.html>; Robert Mandel, 'The Privatization of Security

', Conference Paper 
(International Studies Association, 41th Annual Convention, Los Angeles, CA., 14-18 March 2000) .

4. Christopher Spearin, 'American Hegemony Incorporated: The Importance and Implications of Military Contractors in Iraq', Contemporary Security Policy, Vol.24, No.3 (2003), pp.26-47; David Isenberg, 'A Fistful of Contractors: The Case for a Pragmatic Assessment of Private Military Companies in Iraq', Research Report 2004.4 (London: BASIC, Sept. 2004).

5. Cleaver, 'Subcontracting Military Power'; Howe, 'Global Order and Security Privatization'; Arnold, Mercenaries; Greg Mills and John Stremlau, The Privatisation of Security in Africa (Johannesburg: SAIIA, 1999). Studies with a European and North American focus on the privatization of military force include Martin Edmonds, 'Defense Privatization: From State Enterprise to Commercialism', Cambridge Review of International Affairs, Vol.13, No.1 (1998), pp.114-29; Eric Fredland and Adrian Kendry, 'The Privatisation of Military Force: Economic Virtues, Vices and Government Responsibility', Cambridge Review of International Affairs, Vol.13, No.1 (1998), pp.147-64.

6. Doug Brooks, 'Messiahs or Mercenaries? The Future of International Military Services', International Peacekeeping, Vol.7, No.4 (2000), pp.129-44; Howe, 'Global Order and Security Privatization'.

7. Brooks, 'Messiahs or Mercenaries?', p.131. See also James Larry Taulbee, 'Mercenaries, Private Armies and Security Companies in Contemporary Policy', International Politics, Vol.37, No.4 (2000), pp.433-56, at p.448; and Zarate, 'The Emergence of a New Dog of War', p.124.

8. Brooks, 'Messiahs or Mercenaries?', p.131. See also Mandel, 'The Privatization of Security', p.8; Howe, 'Global Order and Security Privatization', p.308.

9. Zarate, 'The Emergence of a New Dog of War', pp.146-7; Thomas K. Adams, -The New Mercenaries and the Privatization of Con'ict', Parameters (Summer 1999), pp.103-16.

10. Cleaver, 'Subcontracting Military Power', p.143; Damian Lilly, The Privatization of Security and Peacebuilding: A Framework for Action (London: International Alert, 2000), p.25.

11. David Shearer, Private Armies and International Intervention, Adelphi Paper 316 (Oxford: Oxford University Press for IISS, 1998), pp.43-5; less so: Cleaver, 'Subcontracting Military Power', pp.139'40; Howe, 'Global Order and Security Privatization', pp.318-20.

12. Cleaver, 'Subcontracting Military Power', p. 141; Taulbee, 'Mercenaries', p. 447; Lilly, The Privatization of Security, p. 21.

13. Brooks, 'Messiahs or Mercenaries?', p. 137; David Shearer, 'Private Military Force and Challenges for the Future', Cambridge Review of International Affairs, Vol.13, No.1 (1999), pp.80-94, at p.92.

14. Kim Richard Nossal, 'Global Governance and National Interests: Regulating Transnational Security Corporations in the Post-Cold War Era', Melbourne Journal of International Law, Vol.2, No.2 (2001), pp.459-76, at pp.460-61; Mills and Stremlau, The Privatisation of Security in Africa.

15. Nossal, 'Global Governance and National Interests', pp.470-72; David Kassebaum, 'A Question of Facts? The Legal Use of Private Security Firms in Bosnia', Columbia Journal of Transnational Law, Vol.38, No.3 (2000), pp.581-602, at p.589; Zarate, 'The Emergence of a New Dog of War', pp.120-23.

16. Nossal, 'Global Governance and National Interests', pp.473-4; Bruce D. Grant, 'U.S. Military Expertise for Sale: Private Military Consultants as a Tool of Foreign Policy', Strategy Essay Competition Essay (Institute for National Strategic Studies, 1998) www.ndu.edu/inss/books/essaysch4.html>, p.2; Ken Silverstein, 'Privatizing War. How Affairs of State Are Outsourced to Corporations Beyond Public Control', National Magazine, No.4 (Aug. 1997), p.1; Taulbee, 'Mercenaries', p.440.

17. Taulbee, 'Mercenaries', p.449; Mills and Stremlau, 'The Privatisation of Security in Africa', p.14; Jeffrey Herbst, 'The Regulation of Private Security Forces', in Greg Mills and John Stremlau (eds.), The Privatisation of Security in Africa (Johannesburg: SAIIA, 1999), pp.107-27, at p.117; Nossal, 'Global Governance and National Interests', p.461. 
18. United Nations, International Convention against the Recruitment, Use, Financing and Training of Mercenaries, A/RES/44/34, 4 Dec. 1989 res/44/a44r034.htm>. See also Kassebaum, 'A Quest ion of Facts', pp.590'92; Zarate, 'The Emergence of a New Dog of War', pp.123-5, 131.

19. Geneva Convention, Protocol Additional to the Geneva Conventions of 12 August 1949, and relating to the Protection of Victims of International Armed Con'icts, (Protocol I), Article 4.

20. Nossal, 'Global Governance and National Interests', p.471; Zarate, 'The Emergence of a New Dog of War', pp.127-8.

21. Nossal, 'Global Governance and National Interests', pp.464-8. For a critique of the South African law see Mark Malan and Jakkie Cilliers, Mercenaries and Mischief: The Regulation of Foreign Military Assistance Bill (Institute for Security Studies, South Africa, Occasional Paper, 1997).

22. Elke Krahmann, 'Controlling Private Military Services in the UK and Germany: Between Partnership and Regulation', European Security (forthcoming 2005); Ann R. Markusen, 'The Case Against Privatizing National Security', Governance, Vol.16, No.4 (2003), pp.471'501.

23. 'From Building Camps to Gathering Intelligence, Dozens of Tasks Once in the Hands of Soldiers Are Now Carried Out by Contractors', Financial Times, 11 Aug. 2003.

24. Isenberg, 'A Fistful of Contractors', pp.80'99.

25. Thomas Catan, 'Private Military Companies: Seeking a Change of Image', Financial Times, 1 Dec. 2004; Richard Norton-Taylor, 'Big Role Predicted for Security Firms', Guardian, 7 Dec. 2004.

26. ArmorGroup, Global Reach ' Middle East East.asp>. See also Andrew Pierce, 'Rifkind is Made Head of Security Company', The Times, 13 April 2004.

27. Erinys, Iraq . See also Linda S. Heard,

'History Won't Ignore Pentagon's Role in Iraq', Financial Times, 20 April 2004; David Barstow, 'Security Companies: Shadow Soldiers in Iraq', New York Times, 19 April 2004.

28. Anthony Loyd and Daniel McGrory, '5 British Civilians Die in Baghdad Bomb Ambush', The Times, 25 May 2004. Further information on the services offered by Control Risks Group is available from their website.

29. News Release, 'CSC's DynCorp International awarded $\$ 50$ million contract to support law enforcement functions in Iraq' .

30. Press Release, 'Northrop Grumman awarded $\$ 48$ million contract to train new Iraqi army'.

31. The US armaments companies Raytheon and Northrop Grumman, for instance, are seeking to enter the domestic security market after its expansion due to the creation of the Department of Homeland Security (New York Times, 6 April 2003).

32. Brooks, 'Messiahs or Mercenaries?', p.129; Lilly, The Privatization of Security, p.8; Cleaver, 'Subcontracting Military Power', p.136; Taulbee, 'Mercenaries', p.437.

33. For similar reasons, Mandel, Armies without States, pp.99-106, suggests a taxonomy of 'privatized security' according to the scope, source, form and function of private security services.

34. Isenberg, 'A Fistful of Contractors', p.15; Taulbee, 'Mercenaries', p.437; Cleaver, 'Subcontracting Military Power', p.136.

35. CoESS, Panoramic Overview of Private Security Industry in the 25 Member States of the European Union (CoESS, 2004).

36. Tina Weber, Vergleichender Uberblick uber die Rechtsvorschriften zur Regelung des Wachund Sicherheitsgewerbes in der Europaischen Union (Birmingham: ECOTEC, 2002), p.5.

37. Ibid.; CoESS, Panoramic Overview.

38. CoESS, Panoramic Overview.

39. Ibid.

40. Ibid.

41. Council Joint Action 2000/401/CFSP of 22 June 2000 concerning the control of technical assistance related to certain military end-uses, Of'cial Journal L159 (30 June 2000). 
42. Ibid.

43. Council Common Position 2003/468/CFSP of 23 June 2003 on the control of arms brokering, Of'cial Journal L156 (25 June 2003).

44. Ibid.

45. BAFA, Export Controls 'Brief Outline (Eschborn: Federal Of'ce of Economics and Export Control, 2004), pp.8-9.

46. Ibid.

47. DTI, Export of Goods, Transfer of Technology and Provision of Technical Assistance (Control) Order 2003, Statutory Instrument 2003 No.2764 gov.uk/si/si2003/20032764.htm>.

48. Legislative Decree No.96, 9 April 2003

090403_en.pdf>. See also Alberto Traballesi (ed.), 'Controlling the Transfer of Military

Equipment and Technologies in Italy', Supplemento All'Oservatorio Strategico No.12 (Rome,

2004) 4686/suppl_12_04.pdf>.

49. Ibid.

50. BAFA, Export Controls, p.7; DTI, Consultation Document on Draft Orders to be made under the Export Control Act 2002, p.30.

51. See and smallarmssurvey.org/source_documents/Regional\%20fora/European\%20Union/Madrid\% 201

$0-11 \% 20$ may\%202002.pdf>

52. DTI, Trade in Controlled Goods (Embargoed Destinations) Order 2004, Statutory Instru-

ment 2004 No. 318 ; DTI, Trade in Goods (Control) Order 2003, Statutory Instrument 2003 No.2765 legislation.hmso.gov.uk/si/si2003/20032765.htm>.

53. DTI, Trade in Controlled Goods (Embargoed Destinations) Order 2004.

54. DTI, Trade in Goods (Control) Order 2003.

55. See and larmssurvey.org/source_documents/Regional\%20fora/European\%20Union/Madrid\%2010$11 \% 20$ may\%202002.pdf>.

56. Act on the Export and Transit of Defence Materiel (242/1990; amendments up to 900/2002 included).

57. Government Communication 2001/02:114, Report on Sweden's Export Control Policies and Exports of Military Equipment in 2001 skr0102_114e.pdf>.

58. See Section 10.

59. Janice E. Thompson, 'State Practices, International Norms and the Decline of Mercenarism', International Studies Quarterly, Vol.34, No.1 (1990), pp.23-47, at p.35.

60. Foreign and Commonwealth Of'ce (FCO), Private Military Companies: Options for Regulation, HC577 (London: The Stationary Office, 2002)

hc577.pdf >. See also the discussion of the Green Paper in the Commons and the formal response by the British government in Foreign Affairs Committee, Ninth Report 'Private Military Companies, HC 922 (London: The Stationary Office, 1 Aug. 2002) www.parliament.the-

stationery-of'ce.co.uk/pa/cm200102/cmselect/cmfaff/922/922.pdf>

and Response of the Secretary of State for Foreign and Commonwealth Affairs, Ninth

Report of the Foreign Affairs Committee 'Private Military Companies', Oct. 2002.

61. Clayton Hirst, 'No More Must They Cry Havoc and Let Slip the Dogs of War', Independent, 28 Nov 2004.

62. FCO, Private Military Companies, pp.22-6.

63. Ibid., p. 23; Foreign Affairs Committee, Ninth Report, para.102.

64. FCO, Private Military Companies, p.24.

65. Ibid.

66. Ibid., p.25.

67. Foreign Affairs Committee, Ninth Report, para.123. 
68. Ibid., para.134.

69. FCO, Private Military Companies, p.26; Foreign Affairs Committee, Ninth Report, para.137.

70. For an overview of security related export controls in the EU see ExportCTRL/en/main.htm\#SCRL4>.

71. See Court of Justice of the EU, Case Law, Rulings C-114/97 (vs. Spain), C-355/98 (vs.

Belgium), C-283/99 (vs. Italy), and C-189/03 (vs. Netherlands).

72. The Legislative Observatory, Reference CNS/2002/0802. See also 'Draft Report on the Initiative by the Kingdom of Spain for the adoption of a Council decision on the setting up of a Network of contact points of national authorities responsible for private security', Provisional 2002.0802 (CNS), PR\462973EN.doc.

73. Official Journal C153/1 (27 June 2002).

74. News Message, 'CoESS signs a Code of Conduct for Private Security Sector' www.coess.org/ne030718.htm>.

75. For a list (in French) of all negative measures against third countries adopted through the CFSP see .

76. EU Commission ' External Relations, 'Sanctions or Restrictive Measures in Force' (Jan. 2005) .

77. Common Position 96/746/CFSP of 17 December 1996 defined by the Council on the basis of Article J.2 of the Treaty on EU concerning the imposition of an embargo on arms, munitions and military equipment on Afghanistan, Official Journal L342 (31 Dec. 1996).

78. Common Position 1999/206/CFSP of 15 March 1999 defined by the Council on the basis of Article J.2 of the Treaty on EU, concerning Ethiopia and Eritrea, Of'cial Journal L72 (18 March 1999).

79. Common Position 96/184/CFSP of 26 February 1996 defined by the Council on the basis of Article J.2 of the Treaty on EU concerning arms exports to the former Yugoslavia, Of'cial Journal L58 (7 March 1996).

80. Council Decision 93/614/CFSP of 22 November 1993 on the common position defined on the basis of Article J.2 of the Treaty on EU with regard to the reduction of economic relations with Libya, Of' cial Journal L295 (30 Nov. 1993), and Council Regulation (EC) No.3274/93 of 29 November 1993 preventing the supply of certain goods and services to Libya, Of'cial Journal L295 (30 Nov. 1993).

81. Common Position 95/515/CFSP of 20 November 1995 defined by the Council on the basis of Article J.2 of the Treaty on EU, on Nigeria, Official Journal L298 (11 Dec. 1995).

82. Council Regulation (EC) No 1030/2003 of 16 June 2003 concerning certain restrictive measures in respect of Liberia, Of'cial Journal L150 (18 June 2003). Italics added.

83. Sami Makki, Sarah Meek, Abdel Fatau Musah, Michael Crowley and Damian Lilly, Private Military Companies and the Proliferation of Small Arms: Regulating the Actors (London: International Alert, 2001).

84. Joint Action 1999/34/CFSP of 17 December 1998 adopted by the Council on the basis of Article J.3 of the Treaty on EU on the EU's contribution to combating the destabilizing accumulation and spread of small arms and light weapons, Of'cial Journal L9 (15 Jan. 1999).

85. Ibid.

86. Council Joint Action 2002/589/CFSP of 12 July 2002 on the EU's contribution to combating the destabilizing accumulation and spread of small arms and light weapons and repealing Joint Action 1999/34/CFSP, Official Journal L191 (19 July 2002).

87. Council Decision 1999/730/CFSP of 15 November 1999 implementing Joint Action 1999/ 34/CFSP with a view to a EU contribution to combating the destabilizing accumulation and spread of small arms and light weapons in Cambodia, Official Journal L294 (16 Nov. 1999) and Council Decision 2002/904/CFSP of 11 November 2002 extending and amending Decision 1999/730/CFSP concerning a EU contribution to combating the destabilizing accumulation and spread of small arms and light weapons in Cambodia, Of'cial Journal L313 (16 Nov. 2002).

88. Council Decision 2000/803/CFSP of 14 December 2000 implementing Joint Action 1999/ 34/CFSP with a view to a EU contribution to combating the destabilizing accumulation 
and spread of small arms and light weapons in South Ossetia, Of'cial Journal L326 (22 Dec. 2000).

89. Council Decision 1999/845/CFSP of 17 December 1999 implementing Joint Action 1999/ 34/CFSP with a view to a EU contribution to combating the destabilizing accumulation and spread of small arms and light weapons in Mozambique, Official Journal L326 (18 Dec. 1999).

90. EU, The Council, EU Code of Conduct on Armaments Exports, Brussels, 5 June 1998, 8675/ 2/98 Rev 2.

91. Annual Report in Conformity with Operative Provision 8 of the EU Code of Conduct on Arms Exports, Official Journal C315 (3 Nov. 1999).

92. Second Annual Report According to Operative Provision 8 of the EU Code of Conduct on Arms Exports, Of'cial Journal C379 (29 Dec. 2000); Third Annual Report According to Operative Provision 8 of the EU Code of Conduct on Arms Exports, Of'cial Journal C351 (11 Dec. 2001).

93. Fifth Annual Report According to Operative Provision 8 of the EU Code of Conduct on Arms Exports, Official Journal C320 (31 Dec. 2003).

94. See Annual Reports 1999, 2000, 2002, 2003.

95. See.

96. Second Annual Report According to Operative Provision 8 of the EU Code of Conduct on Arms Exports, Official Journal C379 (29 Dec. 2000), p.3.

97. Third Annual Report According to Operative Provision 8 of the EU Code of Conduct on Arms Exports, Official Journal C351 (11 Dec. 2001), pp.3-4.

98. Council Common Position 2003/468/CFSP of 23 June 2003 on the control of arms brokering, Official Journal L156 (25 June 2003).

99. See for instance, Amnesty International, Undermining Global Security: The European Union's Arms Exports (Feb. 2004) .

100. Council Regulation (EC) No 1334/2000 of 22 June 2000 setting up a Community regime for the control of exports of dual-use items and technology, Official Journal L159 (30 June 2000). 